\title{
Relationships Between Yield and Mineral Concentrations in Potato Tubers
}

\author{
Philip J. White ${ }^{1}$, John E. Bradshaw, M. Finlay B. Dale, and Gavin Ramsay \\ Scottish Crop Research Institute, Invergowrie, Dundee DD2 5DA, UK \\ John P. Hammond \\ Warwick HRI, University of Warwick, Wellesbourne, Warwick CV35 9EF, UK \\ Martin R. Broadley \\ University of Nottingham, Sutton Bonington, Leicestershire LE12 5RD, UK
}

Additional index words. fertilizer, nitrogen $(\mathrm{N})$, phosphorus $(\mathrm{P})$, potassium $(\mathrm{K})$, genetics, nutrition

\begin{abstract}
There is concern that modern cultivars and/or agronomic practices have resulted in reduced concentrations of mineral elements essential to human nutrition in edible crops. Increased yields are often associated with reduced concentrations of mineral elements in produce, and a number of recent studies have indicated that, when grown under identical conditions, the concentrations of several mineral elements are lower in genotypes yielding more grain or shoot biomass than in older, lower-yielding genotypes. Potato is a significant crop, grown worldwide, yet few studies have investigated whether increasing yields, through agronomy or breeding, affects the concentrations of mineral elements in tubers. This article examines the hypothesis that increasing yields, either by the application of mineral fertilizers and/or by growing higher-yielding varieties, leads to decreased concentrations of mineral elements in tubers. It reports that the application of fertilizers influences tuber elemental composition in a complex manner, presumably as a consequence of soil chemistry and interactions between mineral elements within the plant, that considerable variation exists between potato genotypes in the concentrations of mineral elements in their tubers, and that, like in other crops, higher-yielding genotypes occasionally have lower concentrations of some mineral elements in their edible tissues than lower-yielding genotypes.
\end{abstract}

\section{MINERAL ELEMENTS REQUIRED BY HUMANS}

Humans require at least 22 mineral elements for their well-being (White and Broadley, 2005a). These can all be supplied by an appropriate diet. However, it is estimated that over $60 \%$ of the world's six billion people are iron $(\mathrm{Fe})$-deficient, over $30 \%$ are zinc $(\mathrm{Zn})$ deficient, 30\% are iodine (I)-deficient, and $\approx 15 \%$ are selenium (Se)-deficient (Welch and Graham, 2002; White and Broadley, 2005a). Deficiencies of calcium (Ca), magnesium $(\mathrm{Mg})$, and copper $(\mathrm{Cu})$ are also common in both developed and developing countries. This situation has been attributed to sourcing produce from land with low mineral phytoavailability, eating crops with inherently low tissue mineral concentrations, and/or consuming the refined foods of civilization. In particular, it appears that the occurrences of Fe-deficiency anemia, $\mathrm{Zn}$ deficiency disorders, and Ca-deficiency disorders have increased dramatically in populations changing from traditional diets dominated by pulses, vegetables, and fruits to diets dominated by cereals (Graham et al.,

Received for publication 24 Mar. 2008. Accepted for publication 7 June 2008.

This work was supported at SCRI by the Scottish Executive Environment and Rural Affairs Department. The work of PJW, MRB, and JPH on potato agronomy is supported by grants HH3504SPO and HH3509SFV from the U.K. Department for Environment, Food and Rural Affairs.

We thank Helen Bowen, Rory Hayden, and Will Spracklen for facilitating the mineral analysis of the SCRI Core Collection and Bruce Marshall for statistical advice.

${ }^{1}$ To whom reprint requests should be addressed; e-mail philip.white@scri.ac.uk
2001; Welch and Graham, 2002), whose tissue concentrations of these elements appear to be constrained by an ancient evolutionary heritage (Broadley et al., 2004, 2007; White and Broadley, 2003). In practical terms, mineral malnutrition can be addressed through supplementation, food fortification, well-chosen dietary diversification, and/or increasing mineral concentrations in edible crops (biofortification). The biofortification of crops through application of mineral fertilizers, combined with breeding varieties with an increased ability to acquire mineral elements, is advocated as an immediate agronomic strategy both to increase mineral concentrations in edible produce and to improve yields on infertile soils (White and Broadley, 2005a).

\section{MINERAL COMPOSITION OF POTATOES}

Potatoes are an excellent source of carbohydrates, vitamins, and minerals. A single medium-sized potato weighing $200 \mathrm{~g}$ fresh weight (FW) can provide $\approx 26 \%$ of the U.S. Dietary Reference Intake (DRI) of $\mathrm{Cu} ; 17 \%$ to $18 \%$ of the DRI of potassium $(\mathrm{K})$, phosphorus $(\mathrm{P})$, and $\mathrm{Fe}$; and $5 \%$ to $13 \%$ of the DRI of $\mathrm{Zn}, \mathrm{Mg}$, and manganese (Mn) (Table 1). Potatoes are generally not rich in Ca but can be a valuable source of trace elements such as Se and I if fertilized appropriately (Broadley et al., 2006b). Furthermore, because potato tubers have relatively high concentrations of organic compounds that stimulate the absorption of mineral micronutrients by humans such as ascorbate (vitamin C), protein cysteine and various organic and amino acids (U.S. Department of Agriculture, Agricultural Research Service, 2006) and low concentrations of compounds that limit their absorption such as phytate $[0.11 \%$ to $0.27 \%$ dry matter (DM); Frossard et al., 2000; Phillippy et al., 2004] and oxalate $(0.03 \%$ DM; Bushway et al., 1984), the bioavailability of mineral elements in potatoes is potentially high.

\section{HISTORICAL VARIATION IN MINERAL CONCENTRATIONS IN EDIBLE HORTICULTURAL PRODUCTS}

Mayer (1997) drew attention to a possible decline in the mean DM content and mean concentrations of $\mathrm{Ca}, \mathrm{Cu}, \mathrm{Mg}$, and sodium $(\mathrm{Na})$ in raw vegetables and $\mathrm{Cu}, \mathrm{Fe}, \mathrm{K}$, and $\mathrm{Mg}$ concentrations in fresh fruits available in the United Kingdom between the 1930s and 1980s. Subsequently, White and Broadley (2005b) expressed the concentrations of mineral elements in U.K. produce on a DM basis to remove any effects of tissue hydration and confirmed that the mean concentrations of $\mathrm{Cu}, \mathrm{Mg}$, and $\mathrm{Na}$ in the $\mathrm{DM}$ of vegetables and the mean concentrations of $\mathrm{Cu}, \mathrm{Fe}$, and $\mathrm{K}$ in the DM of fruits available in the United Kingdom had decreased significantly between the 1930s and the 1980s. White and Broadley (2005b) also analyzed comparable data from the United States and observed that the mean $\mathrm{Ca}, \mathrm{Cu}$, and $\mathrm{Fe}$ concentrations in the DM of vegetables and the mean concentrations of $\mathrm{Cu}, \mathrm{Fe}$, and $\mathrm{K}$ in the $\mathrm{DM}$ of fruits had decreased significantly since the 1930 s. Both these publications used geometric means and $t$ tests to support their conclusions. At the same time, Davis et al. (2004) used medians and sign (quantile) tests to conclude that the moisture-adjusted concentrations of $\mathrm{Ca}, \mathrm{Fe}$, and $\mathrm{P}$ in horticultural 
Table 1. The mineral content of $200 \mathrm{~g}$ fresh weight of potatoes and its contribution to the U.S. Dietary Reference Intake (DRI). ${ }^{\mathrm{z}}$

\begin{tabular}{lccccc}
\hline & & & US & UK & Percent \\
& & DRI & potatoes & potatoes & DRI \\
\hline $\mathrm{N}$ & $(\mathrm{mg})$ & $\mathrm{NS}$ & & 660 & - \\
$\mathrm{S}$ & $(\mathrm{mg})$ & $\mathrm{NS}$ & & 60 & - \\
$\mathrm{K}$ & $(\mathrm{mg})$ & 4700 & 850 & 720 & 18 \\
$\mathrm{Cl}$ & $(\mathrm{mg})$ & 2300 & & 132 & - \\
$\mathrm{Ca}$ & $(\mathrm{mg})$ & 1000 & 22 & 10 & 2.2 \\
$\mathrm{P}$ & $(\mathrm{mg})$ & 700 & 118 & 74 & 17 \\
$\mathrm{Na}$ & $(\mathrm{mg})$ & 1500 & 12 & 14 & 0.8 \\
$\mathrm{Mg}$ & $(\mathrm{mg})$ & 420 & 45 & 34 & 11 \\
$\mathrm{Fe}$ & $(\mathrm{mg})$ & 8 & 1.4 & 0.8 & 18 \\
$\mathrm{Zn}$ & $(\mathrm{mg})$ & 11 & 0.6 & 0.6 & 5.5 \\
$\mathrm{Mn}$ & $(\mathrm{mg})$ & 2.3 & 0.3 & 0.2 & 13 \\
$\mathrm{Cu}$ & $(\mu \mathrm{g})$ & 900 & 231 & 160 & 26 \\
$\mathrm{I}$ & $(\mu \mathrm{g})$ & 150 & 37 & 6 & 25 \\
$\mathrm{Se}$ & $(\mu \mathrm{g})$ & 55 & 0.8 & 2 & 1.4 \\
\hline
\end{tabular}

${ }^{\mathrm{z}}$ Mineral contents are means of four potato varieties available in the United States (unspecified varieties, flesh, and skin; U.S. Department of Agriculture, Agricultural Research Service, 2006) or the United Kingdom (Desiree, King Edwards, Maris Piper, and Pentland Crown varieties, flesh only; Food Standards Agency, 2002) with the exception of US potato iodine, which was taken from True et al. (1978). The DRI values are those for a 31- to 50-year-old male (National Academy of Sciences, 2004)

$\mathrm{NS}=$ not specified.

produce available in the United States had declined between 1950 and 1999. Davis (2006) noted that the conclusion of declining mineral concentrations in produce depended critically on the statistical method used, observing that nonparametric tests indicated that only $\mathrm{Cu}$ and $\mathrm{Na}$ concentrations in the DM of vegetables and the concentrations of no minerals in the DM of fruits available in the United Kingdom had decreased significantly between the 1930s and the 1980s. Nevertheless, the observation that similar changes in the geometric mean and median concentrations of mineral elements in vegetables have occurred in both the United Kingdom and United States, which share similar historical horticultural and consumer practices, suggests that this phenomenon might be a consequence of the adoption of modern varieties and/or agronomic practices (White and Broadley, 2005b). Unfortunately, none of the studies mentioned provide sufficient data to determine whether mineral concentrations of any single vegetable or fruit have altered significantly over time either in the United Kingdom or in the United States. Ultimately, different varieties and/or cultivation practices must be compared directly under the same environmental conditions to determine whether mineral concentrations in a particular crop have been affected by changing cultivars or agricultural practices (Broadley et al., 2006a; Davis, 2006; Davis et al., 2004).

It has been hypothesized that increasing yields has resulted in decreased concentrations of mineral elements in produce because of a "dilution effect" caused by plant growth rates exceeding the ability of plants to acquire these elements (Jarrell and Beverly, 1981) that is impacted by both environmental and genetic factors (Davis, 2005; Davis et al.,
2004). It has long been appreciated that environmental factors accelerating plant growth rates such as higher temperatures, light intensity, and irrigation often result in reduced concentrations of macronutrient elements in plant tissues (Jarrell and Beverly, 1981), and a number of recent studies have shown that the concentrations of various mineral elements are lower in higher-yielding genotypes (Davis et al., 2004; Garvin et al., 2006; Monasterio and Graham, 2000). Monasterio and Graham (2000) observed a strong linear relationship between year of release and grain yield and negative trends between grain $\mathrm{Fe}, \mathrm{Zn}$, and $\mathrm{P}$ concentrations and date of release in a historical set of 26 bread wheat cultivars grown together at two locations over 3 years. Similarly, in a study of 14 U.S. hard red winter wheat varieties grown together at two locations, Garvin et al. (2006) observed negative relationships between seed $\mathrm{Fe}, \mathrm{Zn}$, and Se concentrations and both grain yields and date of release, although the extent to which this effect manifested itself was influenced by the environment. Strong negative relationships between seed $\mathrm{P}$ and sulfur $(\mathrm{S})$ and grain yields were also observed in these field trials (Garvin et al., 2002). In leafy vegetables, Farnham et al. (2000) found strong negative relationships between head weight and $\mathrm{Ca}$ and $\mathrm{Mg}$ concentrations among 27 broccoli genotypes, and Broadley et al. (2008) observed weak negative relationships between shoot biomass and shoot $\mathrm{Ca}$ concentrations among genotypes of Brassica oleracea var. gongylodes (kohlrabi) and var. sabauda (Savoy cabbage) and between shoot biomass and shoot $\mathrm{Mg}$ concentrations among genotypes of B. oleracea var. acephala (kale/ collards) and var. gongylodes (Broadley et al., 2008). This article examines the effects of fertilizer applications on the concentrations of mineral elements in potato tubers, the extent of genetic variation in the concentrations of mineral elements in potato tubers, and the hypothesis that increased yields, produced either by the application of mineral fertilizers and/or by growing higher-yielding varieties, lead to decreased concentrations of mineral elements in potato tubers.

\section{EFFECTS OF FERTILIZER APPLICATION ON TUBER MINERAL CONCENTRATIONS}

Yields of potatoes have increased significantly over the last 50 years as a result of the widespread use of fungicides, fertilizers, and irrigation. The application of mineral fertilizers to the potato crop accelerates plant growth and increases tuber yield (e.g., Allison et al., 2001a, 2001b, 2001c; Birch et al., 1967; Eppendorfer et al., 1979; Harris, 1992; Johnston et al., 1986; Neeteson and Wadman, 1987; Simmons and Kelling, 1987; Trehan and Sharma, 2003; White et al., 2005). It is evident that applying nitrogen $(\mathrm{N})$ fertilizers increases tuber $\mathrm{N}$ concentrations (e.g., Augustin, 1975; Eppendorfer et al., 1979; Harris, 1992; Sen Tran and Giroux, 1991), applying $\mathrm{P}$ fertilizers increases tuber $\mathrm{P}$ concentrations (Allison et al., 2001a; AlvarezSánchez et al., 1999; Hammond and White, 2005; Rocha et al., 1997; Simpson, 1962; Trehan and Sharma, 2003), applying K fertilizers increases tuber $\mathrm{K}$ concentrations (Addiscott, 1976; Allison et al., 2001b; Harris, 1992; Maier, 1986), and applying $\mathrm{Ca}$ or $\mathrm{Mg}$ fertilizers increases tuber Ca (Bamberg et al., 1993, 1998; Clough, 1994; Karlsson et al., 2006; McGuire and Kelman, 1984, 1986; Simmons and Kelling, 1987) and Mg concentrations (Allison et al., 2001c), respectively. In addition, the application of these fertilizers can also affect the concentrations of other mineral elements in tubers. For example, although the application of $\mathrm{N}$ fertilizers often has little effect on tuber $\mathrm{K}, \mathrm{Ca}$, and $\mathrm{Mg}$ concentrations, it can lead to a decrease in tuber $\mathrm{Fe}$ and $\mathrm{P}$ concentrations (Allison et al., 2001c; Augustin, 1975; Harris, 1992; Simpson, 1962), the application of $\mathrm{P}$ fertilizers can increase tuber $\mathrm{N}$ and $\mathrm{Mg}$ concentrations but may reduce tuber $\mathrm{Mn}$ concentrations (Hammond and White, 2005), the application of $\mathrm{K}$ fertilizers often, but not always, increases tuber $\mathrm{Mg}$ but reduces tuber $\mathrm{Ca}$ and $\mathrm{P}$ concentrations (Addiscott, 1974, 1976; Allison et al., 2001c; Maier, 1986), and the application of $\mathrm{Ca}$ fertilizers generally reduces tuber $\mathrm{Mg}$ concentrations but can increase tuber $\mathrm{P}, \mathrm{S}$, and $\mathrm{K}$ concentrations (Clough, 1994; Simmons and Kelling, 1987). These effects are the result not only of complex interactions between mineral elements in the soil and their consequences for uptake by plants, but also of the effects of tissue mineral composition on the redistribution of elements within the plant. Taken together, these studies indicate that tuber mineral concentrations depend greatly on the phytoavailability of different mineral elements to the crop. Indeed, tuber mineral concentrations vary significantly with location (True et al., 1978) allowing mineral profiling of tubers to be used to verify the regional origin of produce (Anderson et al., 1999; Casañas Rivero et al., 2003; Di Giacomo et al., 2007; Padín et al., 2001). In addition, it has been observed that tuber $\mathrm{P}, \mathrm{S}, \mathrm{K}, \mathrm{Mg}, \mathrm{Fe}$, molybdenum, and $\mathrm{Cu}$ concentrations are often higher in organically grown potatoes, whereas tuber $\mathrm{N}$ and $\mathrm{Mn}$ concentrations are higher in conventionally grown potatoes (Warman and Havard, 1998; Wszelaki et al., 2005). Thus, the complex interactions between minerals in the soil together with interactions between mineral elements in their uptake and distribution within the plant suggest that the differences in tuber mineral concentrations observed under contrasting fertilization regimes are unlikely to be the result of a simple dilution effect resulting from increased yields per se.

Other environmental factors impacting tuber yields include irrigation and elevated $\mathrm{CO}_{2}$ concentrations. Increasing yield through irrigation appears to have little effect on tuber $\mathrm{N}$ or $\mathrm{K}$ concentrations but can increase tuber $\mathrm{P}$ concentration and reduce tuber $\mathrm{Ca}$ and $\mathrm{Mg}$ concentrations (Asfary et al., 1983; Simpson, 
1962). Increasing yield through elevated $\mathrm{CO}_{2}$ has been found to reduce the concentrations of $\mathrm{N}, \mathrm{K}$, and $\mathrm{Mg}$ in tubers at crop maturity (Fangmeier et al., 2002). These studies suggest that increased tuber yield can be associated with a reduction in the concentrations of some, but not all, mineral elements in the tubers.

\section{GENETIC VARIATION IN TUBER MINERAL CONCENTRATIONS}

There is considerable genetic variation in tuber mineral concentrations both between and within Solanum species (Table 2). Tuber $\mathrm{Ca}, \mathrm{Fe}$, and $\mathrm{Zn}$ concentrations have been shown to vary significantly between Solanum species grown under identical conditions (Andre et al., 2007; Bamberg et al., 1993, 1998). Among the Solanum species, S. gourlayi and $S$. microdontum had the highest tuber Ca concentrations, whereas S. kurtzianum and $S$. tuberosum had the lowest tuber $\mathrm{Ca}$ concentrations when supplied with ample $\mathrm{Ca}$ (Bamberg et al., 1993). Although the skin generally has a greater $\mathrm{Ca}$ concentration than the flesh (Ereifej et al., 1998; McGuire and Kelman, 1984, 1986; Wszelaki et al., 2005), differences in tuber $\mathrm{Ca}$ concentration between Solanum species do not appear to be associated simply with differences in skinto-flesh ratios (Bamberg et al., 1993). Andre et al. (2007) observed a strong relationship between tuber $\mathrm{Ca}$ and $\mathrm{Fe}$ concentrations and a weak but significant correlation between $\mathrm{Zn}$ and $\mathrm{Fe}$ concentrations among 74 Andean landraces. They observed that some genotypes from the Ajanhuiri group had exceptionally high tuber $\mathrm{Ca}$ and $\mathrm{Fe}$ concentrations and that tuber size explained $\approx 13 \%$ of the variability in tuber Fe concentrations. When grown under identical conditions, $S$. tuberosum genotypes have been shown to differ in tuber N (Augustin, 1975; Fitzpatrick et al.,
1969; Rexen, 1976), K (Brown et al., 2005; Ereifej et al., 1998; Tekalign and Hammes, 2005; Van Marle et al., 1994; Workman and Holm, 1984), P (Dampney et al., 2002; Ereifej et al., 1998; Randhawa et al., 1984; Tekalign and Hammes, 2005; Trehan and Sharma, 2003), S (Tekalign and Hammes, 2005), Ca (Ereifej et al., 1998; Karlsson et al., 2006; McGuire and Kelman, 1986; Randhawa et al., 1984; Tekalign and Hammes, 2005; Tzeng et al., 1990; Van Marle et al., 1994), Mg (Allison et al., 2001c; Ereifej et al., 1998; Randhawa et al., 1984; Tekalign and Hammes, 2005), Fe (Brown et al., 2005; Ereifej et al., 1998; Randhawa et al., 1984), Zn (Brown et al., 2005; Ereifej et al., 1998; Randhawa et al., 1984; Tekalign and Hammes, 2005), Cu (Ereifej et al., 1998; Randhawa et al., 1984; Tekalign and Hammes, 2005), and Mn concentrations (Brown et al., 2005). Systematic differences in tuber $K$, $\mathrm{Mg}, \mathrm{Fe}, \mathrm{Zn}, \mathrm{Cu}$, and $\mathrm{Mn}$ concentrations

Table 2. Variation in tuber mineral concentrations among Solanum genotypes in diverse trials. ${ }^{\mathrm{z}}$

\begin{tabular}{|c|c|c|c|c|c|}
\hline Element & Genotypes & $\mathrm{N}$ & Trial & Concn $($ mean $\pm \mathrm{SD})$ & Reference \\
\hline $\mathrm{N}$ & S. tuberosum varieties & 33 & Field, low N & $13.2 \pm 2.1$ & Rexen (1976) \\
\hline $\mathrm{N}$ & S. tuberosum varieties & 33 & Field, high $\mathrm{N}$ & $15.8 \pm 2.6$ & Rexen (1976) \\
\hline $\mathrm{N}$ & S. tuberosum varieties & 26 & Field & $11.2 \pm 1.8$ & SCRI, unpublished data \\
\hline $\mathrm{N}$ & S. tuberosum breeding lines & 73 & Field & $17.9 \pm 2.3$ & Fitzpatrick et al. (1969) \\
\hline $\mathrm{N}$ & S. tuberosum breeding lines & 10 & Field & $19.9 \pm 2.6$ & Fitzpatrick et al. (1969) \\
\hline $\mathrm{K}$ & S. tuberosum varieties & 10 & Field & $13.8 \pm 1.7$ & Ereifej et al. (1998) \\
\hline $\mathrm{K}$ & S. tuberosum varieties & 4 & Field & $24.9 \pm 3.5$ & Tekalign and Hammes (2005) \\
\hline $\mathrm{K}$ & S. tuberosum varieties & 26 & Field & $21.3 \pm 1.5$ & SCRI, unpublished data \\
\hline $\mathrm{P}$ & S. tuberosum varieties & 10 & Field & $2.32 \pm 0.65$ & Ereifej et al. (1998) \\
\hline $\mathrm{P}$ & S. tuberosum varieties & 3 & Glasshouse & $2.97 \pm 0.45$ & Trehan and Sharma (2003) \\
\hline $\mathrm{P}$ & S. tuberosum varieties & 4 & Field & $2.85 \pm 0.38$ & Tekalign and Hammes (2005) \\
\hline $\mathrm{P}$ & S. tuberosum varieties & 26 & Field & $1.34 \pm 0.16$ & SCRI, unpublished data \\
\hline $\mathrm{S}$ & S. tuberosum varieties & 4 & Field & $2.38 \pm 1.84$ & Tekalign and Hammes (2005) \\
\hline $\mathrm{S}$ & S. tuberosum varieties & 26 & Field & $1.07 \pm 0.13$ & SCRI, unpublished data \\
\hline $\mathrm{Ca}$ & Solanum species & 21 & Glasshouse, low $\mathrm{Ca}$ & $0.45 \pm 0.14$ & Bamberg et al. (1993) \\
\hline $\mathrm{Ca}$ & Solanum species & 21 & Glasshouse, high $\mathrm{Ca}$ & $1.52 \pm 0.47$ & Bamberg et al. (1993) \\
\hline $\mathrm{Ca}$ & Andean landraces & 74 & Field & $0.50 \pm 0.17$ & Andre et al. (2007) \\
\hline $\mathrm{Ca}$ & Solanum gourlayi & 18 & Glasshouse, low $\mathrm{Ca}$ & $0.37 \pm 0.12$ & Bamberg et al. (1998) \\
\hline $\mathrm{Ca}$ & Solanum gourlayi & 18 & Glasshouse, high $\mathrm{Ca}$ & $1.69 \pm 0.49$ & Bamberg et al. (1998) \\
\hline $\mathrm{Ca}$ & Solanum kurtzianum & 10 & Glasshouse, low $\mathrm{Ca}$ & $0.17 \pm 0.03$ & Bamberg et al. (1998) \\
\hline $\mathrm{Ca}$ & Solanum kurtzianum & 10 & Glasshouse, high $\mathrm{Ca}$ & $0.93 \pm 0.52$ & Bamberg et al. (1998) \\
\hline $\mathrm{Ca}$ & Solanum microdontum & 8 & Glasshouse, low $\mathrm{Ca}$ & $0.26 \pm 0.05$ & Bamberg et al. (1998) \\
\hline $\mathrm{Ca}$ & Solanum microdontum & 8 & Glasshouse, high $\mathrm{Ca}$ & $1.87 \pm 0.63$ & Bamberg et al. (1998) \\
\hline $\mathrm{Ca}$ & Solanum phureja & 38 & Field & $0.50 \pm 0.10$ & SCRI, unpublished data \\
\hline $\mathrm{Ca}$ & S. tuberosum varieties & 10 & Field & $1.04 \pm 0.31$ & Ereifej et al. (1998) \\
\hline $\mathrm{Ca}$ & S. tuberosum varieties & 4 & Field & $0.61 \pm 0.08$ & Tekalign and Hammes (2005) \\
\hline $\mathrm{Ca}$ & S. tuberosum varieties & 5 & Field, low Ca & $0.18 \pm 0.05$ & Karlsson et al. (2006) \\
\hline $\mathrm{Ca}$ & S. tuberosum varieties & 5 & Field, high $\mathrm{Ca}$ & $0.22 \pm 0.06$ & Karlsson et al. (2006) \\
\hline $\mathrm{Ca}$ & S. tuberosum varieties & 26 & Field & $0.39 \pm 0.09$ & SCRI, unpublished data \\
\hline $\mathrm{Mg}$ & S. tuberosum varieties & 10 & Field & $1.34 \pm 0.13$ & Ereifej et al. (1998) \\
\hline $\mathrm{Mg}$ & S. tuberosum varieties & 3 & Field, $4 \mathrm{~N}$ rates & $0.98 \pm 0.08$ & Allison et al. (2001c) \\
\hline $\mathrm{Mg}$ & S. tuberosum varieties & 4 & Field & $1.38 \pm 0.14$ & Tekalign and Hammes (2005) \\
\hline $\mathrm{Mg}$ & S. tuberosum varieties & 26 & Field & $1.04 \pm 0.11$ & SCRI, unpublished data \\
\hline $\mathrm{Fe}$ & Andean landraces & 74 & Field & $55.9 \pm 18.2$ & Andre et al. (2007) \\
\hline $\mathrm{Fe}$ & S. tuberosum varieties & 10 & Field & $114 \pm 32.0$ & Ereifej et al. (1998) \\
\hline $\mathrm{Fe}$ & S. tuberosum varieties & 4 & Field & $56.2 \pm 3.98$ & Tekalign and Hammes (2005) \\
\hline $\mathrm{Fe}$ & S. tuberosum varieties & 26 & Field & $75.7 \pm 76.9$ & SCRI, unpublished data \\
\hline $\mathrm{Zn}$ & Andean landraces & 74 & Field & $11.3 \pm 7.8$ & Andre et al. (2007) \\
\hline $\mathrm{Zn}$ & S. tuberosum varieties & 10 & Field & $20.4 \pm 4.2$ & Ereifej et al. (1998) \\
\hline $\mathrm{Zn}$ & S. tuberosum varieties & 4 & Field & $16.6 \pm 3.7$ & Tekalign and Hammes (2005) \\
\hline $\mathrm{Zn}$ & S. tuberosum varieties & 26 & Field & $11.3 \pm 2.2$ & SCRI, unpublished data \\
\hline $\mathrm{Cu}$ & S. tuberosum varieties & 10 & Field & $14.6 \pm 6.85$ & Ereifej et al. (1998) \\
\hline $\mathrm{Cu}$ & S. tuberosum varieties & 4 & Field & $20.0 \pm 1.51$ & Tekalign and Hammes (2005) \\
\hline $\mathrm{Cu}$ & S. tuberosum varieties & 26 & Field & $3.72 \pm 0.70$ & SCRI, unpublished data \\
\hline Mn & S. tuberosum varieties & 10 & Field & $7.80 \pm 1.40$ & Ereifej et al. (1998) \\
\hline Mn & S. tuberosum varieties & 4 & Field & $3.78 \pm 0.56$ & Tekalign and Hammes (2005) \\
\hline Mn & S. tuberosum varieties & 26 & Field & $5.78 \pm 0.57$ & SCRI, unpublished data \\
\hline
\end{tabular}

${ }^{\mathrm{z}}$ Each trial comprised $\mathrm{N}$ genotypes grown under identical conditions. Tuber concentrations of $\mathrm{N}, \mathrm{K}, \mathrm{P}, \mathrm{S}, \mathrm{Ca}$, and $\mathrm{Mg}$ are given in g/kg dry matter. Tuber concentrations of $\mathrm{Fe}, \mathrm{Zn}, \mathrm{Cu}$, and $\mathrm{Mn}$ are given in $\mathrm{mg} / \mathrm{kg}$ dry matter. 
Table 3. Relationships between the concentrations of mineral elements in tubers and tuber yield among N genotypes of Solanum tuberosum in diverse trials. ${ }^{2}$

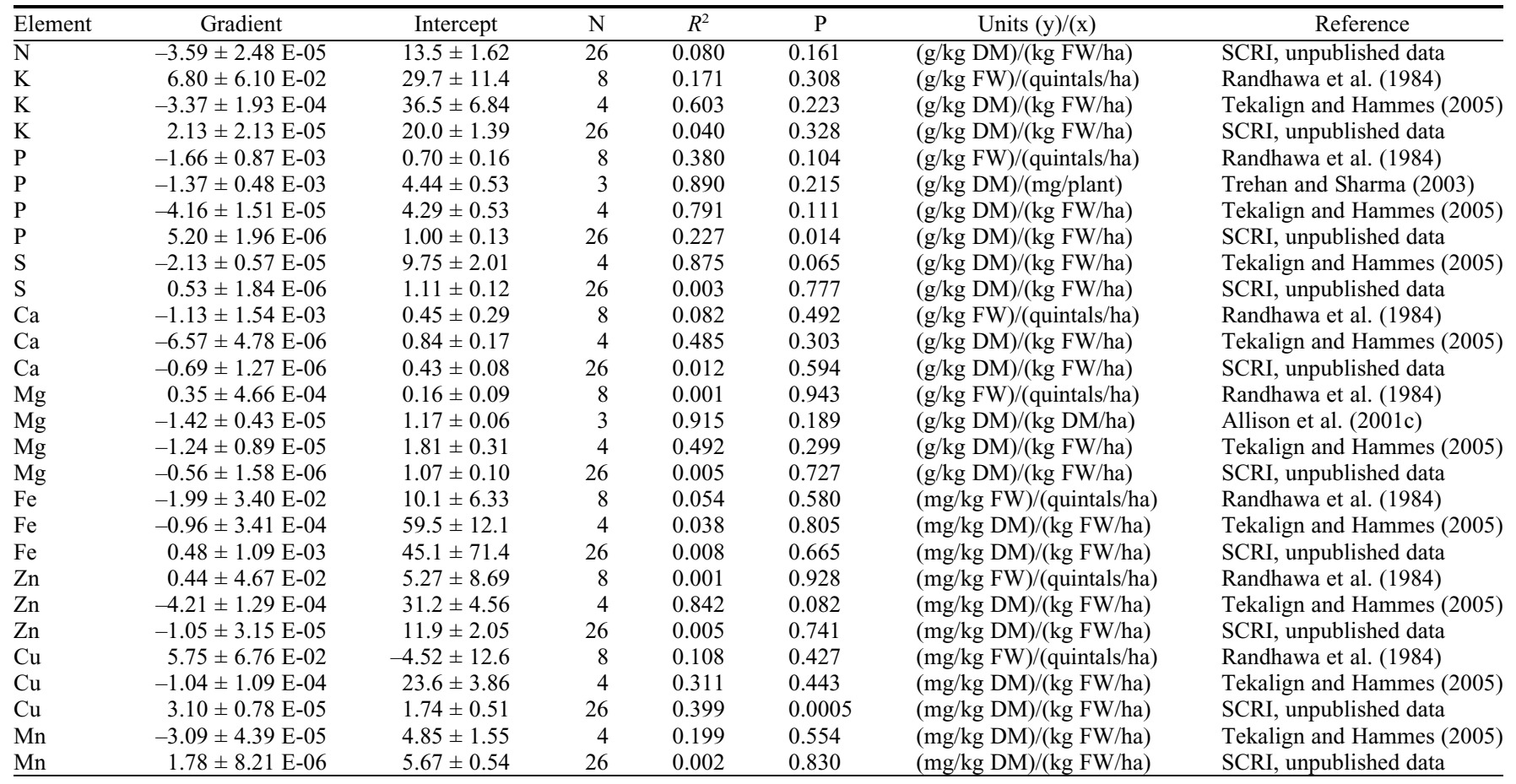

${ }^{\mathrm{z}} \mathrm{A}$ linear relationship $(\mathrm{y}=\mathrm{mx}+\mathrm{c})$ was assumed between the concentration of a mineral element in the tuber $(\mathrm{y})$ and tuber yield $(\mathrm{x})$, and ses on gradients $(\mathrm{m})$ and intercepts (c), correlation coefficients $\left(\mathrm{R}^{2}\right)$, and probability that the gradient is zero $(\mathrm{P})$ were calculated.

have also been observed between potato varieties obtained commercially (Casañas Rivero et al., 2003; Di Giacomo et al., 2007). It is likely, therefore, that tuber mineral concentrations can be manipulated genetically through commercial breeding programs.

\section{LOWER TUBER MINERAL CONCENTRATIONS ARE SOMETIMES OBSERVED IN HIGHER- YIELDING GENOTYPES}

There is some evidence in the literature to suggest that higher-yielding potato genotypes have lower concentrations of mineral elements in their tubers than lower-yielding genotypes when grown in the same environment (Table 3). For example, in studies comparing a small number of genotypes, it has been observed that tuber K (Tekalign and Hammes, 2005), P (Randhawa et al., 1984; Tekalign and Hammes, 2005; Trehan and Sharma, 2003), S (Tekalign and Hammes, 2005), Ca (Randhawa et al., 1984; Tekalign and Hammes, 2005), Mg (Allison et al., 2001c; Tekalign and Hammes, 2005), Fe (Randhawa et al., 1984; Tekalign and Hammes, 2005), Zn (Tekalign and Hammes, 2005), $\mathrm{Cu}$ (Tekalign and Hammes, 2005), and Mn (Tekalign and Hammes, 2005) concentrations are lower in higher-yielding varieties than in lower-yielding varieties grown in the same trial, but none of these relationships are statistically robust. Moreover, Randhawa et al. (1984) found nonsignificant positive relationships between tuber FW yield and tuber $\mathrm{K}$, $\mathrm{Mg}, \mathrm{Zn}$, and $\mathrm{Cu}$ concentrations in their comparison of eight potato varieties.
Recently, a more extensive investigation of genetic variation in concentrations of mineral elements in potato tubers was initiated at the Scottish Crop Research Institute. During this investigation, field trials incorporating 26 commercial potato varieties provided no support for the hypothesis that higher-yielding varieties have lower concentrations of mineral elements in their tubers than lower-yielding varieties (Fig. 1; Table 3 ). In these trials, there were no significant relationships between tuber $\mathrm{FW}$ yield and tuber $\mathrm{N}, \mathrm{K}, \mathrm{S}, \mathrm{Ca}, \mathrm{Mg}, \mathrm{Fe}, \mathrm{Zn}$, or $\mathrm{Mn}$ concentrations, but tuber $\mathrm{P}(P=0.014)$ and
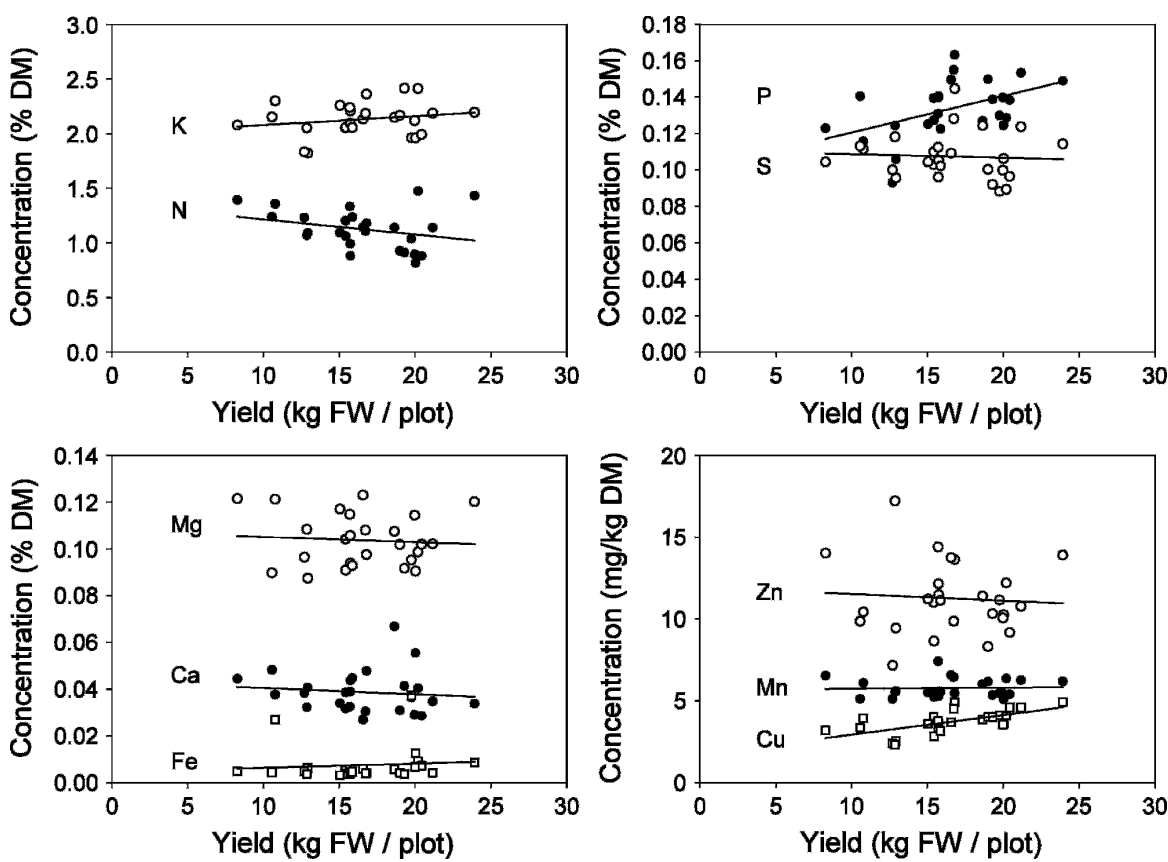

Fig. 1. Relationships between tuber mineral concentrations and tuber yield in a core collection of 26 commercial Solanum tuberosum varieties trialled in the field at SCRI in 2006. Data are means of two replicate plots each containing eight plants at $40 \mathrm{~cm}$ spacing. Yields approximate 32,000 to $92,000 \mathrm{~kg}$ fresh weight/ha. Plant husbandry followed local practice. Statistical parameters for linear regressions are presented in Table 3. 
$\mathrm{Cu}$ concentrations $(P<0.001)$ increased significantly with increasing tuber FW yield. This is possibly the first report in which concentrations of mineral elements in edible produce are significantly positively correlated with yields and suggests that breeding for both increased yields and increased concentrations of mineral elements is feasible.

\section{CONCLUSIONS}

The concentrations of mineral elements in potato tubers are influenced by both environmental and genetic factors. One of the most significant environmental factors is the phytoavailability of mineral elements in the soil. The literature contains some evidence to support the hypothesis that increasing tuber yields, either by elevating $\mathrm{CO}_{2}$ concentrations or by growing higher-yielding varieties, can lead to decreased concentrations of some mineral elements in tubers, but this is not universally observed. A reduction in tuber mineral concentrations might be addressed through appropriate applications of mineral fertilizers. Increasing yields through the application of mineral fertilizers has diverse effects on tuber mineral concentrations depending on the composition of the fertilizer, the soil type, and the crop genotype. Interactions between mineral elements in the soil, and also within the plant, are likely to affect the concentrations of mineral elements in tubers independent of any "yield dilution" phenomenon. Consequently, it should be possible to increase tuber mineral concentrations by combining genotypes that have naturally higher tuber mineral concentrations with appropriate fertilization strategies to deliver more essential minerals to the diet without compromising yield.

\section{Literature Cited}

Addiscott, T.M. 1974. Potassium and the distribution of calcium and magnesium in potato plants. J. Sci. Food Agr. 25:1173-1183.

Addiscott, T.M. 1976. Nutrient concentrations and interactions in young leaves of potato plants growing with and without tubers. Ann. Bot. (Lond.) 40:65-72.

Allison, M.F., J.H. Fowler, and E.J. Allen. 2001a. Effects of soil- and foliar-applied phosphorus fertilizers on the potato (Solanum tuberosum) crop. J. Agr. Sci. 137:379-395.

Allison, M.F., J.H. Fowler, and E.J. Allen. 2001b. Responses of potato (Solanum tuberosum) to potassium fertilizers. J. Agr. Sci. 136:407-426.

Allison, M.F., J.H. Fowler, and E.J. Allen. 2001c. Factors affecting the magnesium nutrition of potatoes (Solanum tuberosum). J. Agr. Sci. 137:397-409.

Alvarez-Sánchez, E., J.D. Etchevers, J. Ortiz, R. Núñez, V. Volke, L. Tijerina, and A. Martínez. 1999. Biomass production and phosphorus accumulation of potato as affected by phosphorus nutrition. J. Plant Nutr. 22:205-217.

Anderson, K.A., B.A. Magnuson, M.L. Tschirgi, and B. Smith. 1999. Determining the geographic origin of potatoes with trace metal analysis using statistical and neural network classifiers. J. Agr. Food Chem. 47:1568-1575.

Andre, C.M., M. Ghislain, P. Bertin, M. Oufir, M. del Rosario Herrera, L. Hoffmann, J.-F. Haus- man, Y. Larondelle, and D. Evers. 2007. Andean potato cultivars (Solanum tuberosum L.) as a source of antioxidant and mineral micronutrients. J. Agr. Food Chem. 55:366-378.

Asfary, A.F., A. Wild, and P.M. Harris. 1983. Growth, mineral nutrition and water use by potato crops. J. Agr. Sci. 100:87-101.

Augustin, J. 1975. Variations in the nutritional composition of fresh potatoes. J. Food Sci. 40:1295-1299.

Bamberg, J.B., J.P. Palta, L.A. Peterson, M. Martin, and A.R. Krueger. 1993. Screening tuberbearing Solanum (potato) germplasm for efficient accumulation of tuber calcium. Amer. Potato J. 70:219-226.

Bamberg, J.B., J.P. Palta, L.A. Peterson, M. Martin, and A.R. Krueger. 1998. Fine screening potato (Solanum) species germplasm for tuber calcium. Amer. J. Potato Res. 75:181-186.

Birch, J.A., J.R. Devine, M.R.J. Holmes, and J.D. Whitear. 1967. Field experiments on the fertilizer requirements of maincrop potatoes. J. Agr. Sci. 69:13-24.

Broadley, M.R., H.C. Bowen, H.L. Cotterill, J.P. Hammond, M.C. Meacham, A. Mead, and P.J. White. 2004. Phylogenetic variation in the shoot mineral concentration of angiosperms. J. Expt. Bot. 55:321-336.

Broadley, M.R., J.P. Hammond, G.J. King, D. Astley, H.C. Bowen, M.C. Meacham, A. Mead, D.A.C. Pink, G.R. Teakle, R.M. Hayden, W.P. Spracklen, and P.J. White. 2008. Shoot calcium and magnesium concentrations differ between subtaxa, are highly heritable, and associate with potentially pleiotropic loci in Brassica oleracea. Plant Physiol. 146:1707-1720.

Broadley, M.R., A. Mead, and P.J. White. 2006a. Reply to Davis (2006) commentary on 'Historical variation in the mineral composition of edible horticultural products'. J. Hort. Sci. Biotechnol. 81:554-555.

Broadley, M.R., P.J. White, R.J. Bryson, M.C. Meacham, H.C. Bowen, S.E. Johnson, M.J. Hawkesford, S.P. McGrath, F.-J. Zhao, N Breward, M. Harriman, and M. Tucker. 2006b. Biofortification of UK food crops with selenium. Proc. Nutr. Soc. 65:169-181.

Broadley, M.R., P.J. White, J.P. Hammond, I. Zelko, and A. Lux. 2007. Zinc in plants. New Phytol. 173:677-702.

Brown, C.R., M. Moore, A.K. Alva, W.L. Boge, and C. Yang. 2005. Genetic variation of mineral content in potato and nutritional considerations. 44th Annual Washington State Potato Conference, 1-3 Feb. 2005, Moses Lake, WA, p. 5-8.

Bushway, R.J., J.L. Bureau, and D.F. McGann. 1984. Determinations of organic acids in potatoes by high performance liquid chromatography. J. Food Sci. 49:75-81.

Casañas Rivero, R., P. Suárez Hernández, E.M. Rodríguez Rodríguez, J. Darias Martín, and C.D. Díaz Romero. 2003. Mineral concentrations in cultivars of potatoes. Food Chem. 83:247-253.

Clough, H.G. 1994. Potato tuber yield, mineral concentration and quality after calcium fertilization. J. Amer. Soc. Hort. Sci. 119:175-179.

Dampney, P., P. Johnson, G. Goodlass, C. Dyer, A Sinclair, and T. Edwards. 2002. Review of the response of potatoes to phosphate. Final Report on Defra Project PE0108.

Davis, D.R. 2005. Trade-offs in agriculture and nutrition. Food Technol. 59:120.

Davis, D.R. 2006. Commentary on 'Historical variation in the mineral composition of edible horticultural products'. J. Hort. Sci. Biotechnol. 81:553-554.
Davis, D.R., M.D. Epp, and H.D. Riordan. 2004. Changes in USDA food composition data for 43 garden crops, 1950 to 1999. J. Amer. Coll. Nutr. 23:669-682.

Di Giacomo, F., A. Del Signore, and M. Giaccio. 2007. Determining the geographic origin of potatoes using mineral and trace element content. J. Agr. Food Chem. 55:860-866.

Eppendorfer, W.H., B.O. Eggum, and S.W. Bille. 1979. Nutritive value of potato crude protein as influenced by manuring and amino acid composition. J. Sci. Food Agr. 30:361-368.

Ereifej, K.I., R.A. Shibli, M.M. Ajlouni, and A. Hussein. 1998. Mineral contents of whole tubers and selected tissues of ten potato cultivars grown in Jordan. J. Food Sci. Technol. $35: 55-58$.

Fangmeier, A., L. De Temmerman, C. Black, K. Persson, and V. Vorne. 2002. Effects of elevated $\mathrm{CO}_{2}$ and/or ozone on nutrient concentrations and nutrient uptake of potatoes. Eur. J. Agron. 17:353-368.

Farnham, M.W., M.A. Grusak, and M. Wang. 2000. Calcium and magnesium concentration of inbred and hybrid broccoli heads. J. Amer. Soc. Hort. Sci. 125:344-349.

Fitzpatrick, T.J., R.V. Akeley, J.W. White, and W.L. Porter. 1969. Protein, non-protein, and total nitrogen in seedlings of potatoes. Amer. Potato J. 46:273-286.

Food Standards Agency. 2002. McCance and Widdowson's The composition of foods. Sixth summary edition. Royal Society of Chemistry, Cambridge, UK.

Frossard, E., M. Bucher, F. Mächler, A. Mozafar, and R. Hurrell. 2000. Potential for increasing the content and bioavailability of $\mathrm{Fe}, \mathrm{Zn}$ and $\mathrm{Ca}$ in plants for human nutrition. J. Sci. Food Agr. 80:861-879.

Garvin, D.F., R.M. Welch, and J.W. Finley. 2006. Historical shifts in the seed mineral micronutrient concentration of US hard red winter wheat germplasm. J. Sci. Food Agr. 86:2213-2220.

Garvin, D.F., R.M. Welch, J.W. Finley, A.K. Fritz, E. Donmez, J.P. Shroyer, and G.M. Paulsen. 2002. Seed micronutrient contents of a historical collection of hard red winter wheats. Abstracts of the Annual Meeting, Am. Soc. Agron./Crop Sci. Soc. Amer./Soil Sci. Soc. Amer., Madison, WI.

Graham, R.D., R.M. Welch, and H.E. Bouis. 2001. Addressing micronutrient malnutrition through enhancing the nutritional quality of staple foods: Principles, perspectives and knowledge gaps. Adv. Agron. 70:77-142.

Hammond, J.P. and P.J. White. 2005. Is struvite a valuable phosphate source for agriculture? Final Report on Entrust Project 675382.006.

Harris, P.M. 1992. Mineral nutrition, p.162-213. In: Harris, P.M. (ed.). The potato crop: The scientific basis for improvement. Chapman and Hall, London, UK.

Jarrell, W.M. and R.B. Beverly. 1981. The dilution effect in plant nutrition studies. Adv. Agron. 34:197-224.

Johnston, A.E., P.W. Lane, G.E.G. Mattingley, P.R. Poulton, and M.V. Hewitt. 1986. Effects of soil and fertilizer $\mathrm{P}$ on yields of potatoes, sugar beet, barley and winter wheat on a sandy clay loam soil at Saxmundham, Suffolk. J. Agr. Sci. 106:155-167.

Karlsson, B.H., J.P. Palta, and P.M. Crump. 2006. Enhancing tuber calcium concentration may reduce incidence of blackspot bruise injury in potatoes. HortScience 41:1213-1221.

Maier, N.A. 1986. Potassium nutrition of irrigated potatoes in South Australia. 2. Effect on chemical composition and the prediction of 
tuber yield response by plant analysis. Aust. J. Exp. Agr. 26:727-736.

Mayer, A.-M. 1997. Historical changes in the mineral content of fruits and vegetables. $\mathrm{Br}$. Food J. 99:207-211.

McGuire, R.G. and A. Kelman. 1984. Reduced severity of Erwinia soft rot in potato tubers with increased calcium content. Phytopathol. 74: 1250-1256.

McGuire, R.G. and A. Kelman. 1986. Calcium in potato tuber cell walls in relation to tissue maceration by Erwinia carotovora pv. atroseptica. Phytopathol. 76:401-406.

Monasterio, I. and R.D. Graham. 2000. Breeding for trace minerals in wheat. Food Nutr. Bull. 21:392-396.

National Academy of Sciences. 2004. Dietary reference intakes (DRIs): Recommended intakes for individuals, elements. 6 Nov. 2008. $<$ http://fnic.nal.usda.gov/nal_display/index.php? info_center $=4 \&$ tax_level $=3 \&$ tax_subject $=256$ \&topic_id=1342\&level3_id $=5140>$.

Neeteson, J.J. and W.P. Wadman. 1987. Assessment of economically optimum application rates of fertilizer $\mathrm{N}$ on the basis of response curves. Fert. Res. 12:37-52.

Padín, P.M., R.M. Peña, S. García, R. Iglesias, S. Barro, and C. Herrero. 2001. Characterization of Galician (N.W. Spain) quality brand potatoes: A comparison study of several pattern recognition techniques. Analyst (Lond.) 126: 97-103.

Phillippy, B.Q., M. Lin, and B. Rasco. 2004. Analysis of phytate in raw and cooked potatoes. J. Food Compost. Anal. 17:217-226.

Randhawa, K.S., K.S. Sandhu, G. Kaur, and D. Singh. 1984. Studies of the evaluation of different genotypes of potato (Solanum tuberosum L.) for yield and mineral contents. Qual. Plant. 34:239-242.
Rexen, B. 1976. Studies of protein of potatoes. Potato Res. 19:189-202.

Rocha, F.A.T., P.C.R. Fontes, R.L.F. Fontes, and F.P. Reis. 1997. Critical phosphorus concentrations in potato plant parts at two growth stages. J. Plant Nutr. 20:573-579.

Sen Tran, T. and M. Giroux. 1991. Effects of N rates and harvest dates on the efficiency of $15 \mathrm{~N}$-labelled fertilizer on early harvested potatoes (Solanum tuberosum L.). Can. J. Soil Sci. 71:519-532.

Simmons, K.E. and K.A. Kelling. 1987. Potato responses to calcium application on several soil types. Amer. Potato J. 64:119-136.

Simpson, K. 1962. Effects of soil-moisture tension and fertilizers on the yield, growth and phosphorus uptake of potatoes. J. Sci. Food Agr. 13:236-248.

Tekalign, T. and P.S. Hammes. 2005. Growth and productivity of potato as influenced by cultivar and reproductive growth. II. Growth analysis, tuber yield and quality. Sci. Hort. 105:29-44.

Trehan, S.P. and R.C. Sharma. 2003. External phosphorus requirement of different potato (Solanum tuberosum) cultivars resulting from different internal requirements and uptake efficiencies. Indian J. Agr. Sci. 73:54-56.

True, R.H., J.M. Hogan, J. Augustin, S.J. Johnson, C. Teitzel, R.B. Toma, and R.L. Shaw. 1978. Mineral composition of freshly harvested potatoes. Amer. Potato J. 55:511-519.

Tzeng, K.-C., R.G. McGuire, and A. Kelman. 1990. Resistance of tubers from different potato cultivars to soft rot caused by Erwinia carotovora subsp. atroseptica. Amer. Potato J. 67:287-305.

U.S. Department of Agriculture, Agricultural Research Service. 2006. USDA National Nutrient Database for Standard Reference, Release
19. Nutrient Data Laboratory home page. May 2007. <http://www.ars.usda.gov/ba/bhnrc/ndl > . Van Marle, J.T., C. Van Dijk, A.G.J. Voragen, and E.S.A. Biekman. 1994. Comparison of the cooking behaviour of the cultivars Nicola and Irene with respect to pectin breakdown and the transfer of ions. Potato Res. 37:183-195.

Warman, P.R. and K.A. Havard. 1998. Yield, vitamin and mineral contents of organically and conventionally grown potatoes and sweet corn. Agr. Ecosyst. Environ. 68:207-216.

Welch, R.M. and R.D. Graham. 2002. Breeding crops for enhanced micronutrient content. Plant Soil 245:205-214.

White, P.J. and M.R. Broadley. 2003. Calcium in plants. Ann. Bot. (Lond.) 92:487-511.

White, P.J. and M.R. Broadley. 2005a. Biofortifying crops with essential mineral elements. Trends Plant Sci. 10:586-593.

White, P.J. and M.R. Broadley. 2005b. Historical variation in the mineral composition of edible horticultural products. J. Hort. Sci. Biotechnol. 80:660-667.

White, P.J., M.R. Broadley, J.P. Hammond, and A.J. Thompson. 2005. Optimising the potato root system for phosphorus and water acquisition in low-input growing systems. Aspects App. Biol. 73:111-118.

Workman, M. and D.G. Holm. 1984. Potato clone variation in blackspot and soft rot susceptibility, redox potential, ascorbic acid, dry matter and potassium. Amer. Potato J. 61:723-733.

Wszelaki, A.L., J.F. Delwiche, S.D. Walker, R.E. Liggett, J.C. Scheerens, and M.D. Kleinhenz. 2005. Sensory quality and mineral and glycoalkaloid concentrations in organically and conventionally grown redskin potatoes (Solanum tuberosum). J. Sci. Food Agr. 85: 720-726. 